\title{
Antimicrobial and Cytotoxic Activities of Root Extracts of Piper Chaba
}

\author{
Tarannum Naz, Ashik Mosaddik and M. Ekramul Haque ${ }^{1}$ \\ Department of Pharmacy, University of Rajshahi, Rajshahi 6205, Bangladesh \\ Received 25 October 2008, accepted in final form 15 November 2008
}

\begin{abstract}
Antibacterial and antifungal properties of petroleum ether, chloroform, ethyl acetate and methanol extracts of Piper chaba (Choi) roots were studied by disc diffusion method and these activities were compared with primary standard drugs Kanamycin and Nystatin, respectively. The extracts were found to exhibit promising antibacterial and antifungal properties against Gram-positive, Gram-negative bacteria and fungi. The extracts were also studied for their cytotoxic activities by brine shrimp lethality bioassay, where gallic acid was used as primary standard. It was observed that the petroleum ether extract was potent cytotoxic with the $\mathrm{LC}_{50}$ value of $0.95 \mu \mathrm{g} / \mathrm{ml}$ against Artemia salina (L). The essential oils of the petroleum ether extract of Piper chaba roots were analysed by GC/MS. It was observed that most of the compounds were sesquiterpenes, some were long chain fatty acids and some were monoterpenes and alkaloids. Seventeen compounds were identified from the GC/MS analysis.
\end{abstract}

Keywords: Piper chaba, antibacterial activity, antifungal activity, cytotoxicity.

(C) 2009 JSR Publications. ISSN: 2070-0237 (Print); 2070-0245 (Online). All rights reserved.

DOI: 10.3329 /jsr.vlil.1446

\section{Introduction}

The plant Piper chaba, which is called Choi locally, belongs to the family piperaceae. The members of this family are claimed to have economic as well as medicinal importance. This family has also found a wide range of applications in the traditional pharmacopoeia of several cultural groups. It is renowned in the Indian Ayurvedic system of medicine, in the folklore of Africa, Latin America and the West Indies as well as in the Chinese herbal medicines. The plant Piper chaba is also an important member of this family. The plant Piper chaba is an annual/perennial shrub, cultivated in India, Malaysia and Bangladesh. In Bangladesh and India, the decoction of the roots of Piper chaba Hunter (Fam: Piperaceae) is used for colic pain, dyspepsia and gastralgia [1, 2]. Essential oils composition study on the Piper species have shown the presence of elemol (11.5\%) in Piper nigrum, $\beta$-caryophyllene (13\%) in Piper attenuatum, $\beta$-cubebene $(10 \%)$ in $P$.

\footnotetext{
${ }^{1}$ Corresponding author: mdekramul@yahoo.com
} 
cubeba, safrole (39.9\%), eugenol (9.0\%), allo-pyrocatechol mono acetate $(8.5 \%)$, terpinen-4-ol (6.3\%) and chavibetol in Piper betel leaf by GC and GC/MS [3]. P.nigrum oil, fruit oil of Piper chaba and P. longum have been found to contain few monoterpene hydrocarbons, a moderate content of sesquiterpenes and high content of aliphatic hydrocarbons by GC and GC/MS analysis [4]. Biological investigations on Piper chaba have shown that chloroform and methanol extracts of Piper chaba show anti-amoebic and anti-giardial activities against Entamoeba histolytica $\left(\mathrm{IC}_{50}\right.$ value of $71.4 \mu \mathrm{g} / \mathrm{ml}$ ) and Giardia intestinalis $\left(\mathrm{IC}_{50}\right.$ value of $<100 \mu \mathrm{g} / \mathrm{ml}$ ) [5, 6]. Extracts of Piper chaba have also been found to exhibit anti-diarrhoeal and diuretic activities [7].

Recently, it has been reported that amides from Piper chaba significantly inhibit ethanol and indomethacin induced gastric lesions at a dose of $25 \mathrm{mg} / \mathrm{kg}$ after oral administration [8]. However, there is no report on chemical or biological investigations on the roots of this plant. In this paper we report antimicrobial and cytotoxic activities of the crude extracts of the roots of Piper chaba and the compositions of the essential oils of petroleum ether extract.

\section{Materials and Methods}

\subsection{Plant collection and extraction}

Roots of Piper chaba were collected from the Bagerhut District, Bangladesh. The plant was botanically identified by Prof. A. T. M. Naderuzzaman, Department of Botany, University of Rajshahi. A voucher specimen was deposited in Bangladesh National Herbarium (Voucher No. 30276).

The extraction was carried out by soaking the dried, grounded roots $(1 \mathrm{~kg})$ of Piper chaba in 5 liter rectified spirit for two weeks at room temperature. Evaporation of the solvent under reduced pressure afforded a semi-solid mass (40 gm). The crude extract was successively partitioned with petroleum ether, chloroform, ethyl acetate and finally with methanol. Solvents of these extracts were concentrated separately by evaporation under reduced pressure below $50{ }^{\circ} \mathrm{C}$, which yielded $10.0 \mathrm{~g}, 12.3 \mathrm{~g}, 1.2 \mathrm{~g}$ and $5.6 \mathrm{~g}$ of the dried extracts, respectively.

\subsection{Test organisms}

Four Gram-positive bacteria (Bacillus subtilis, Bacillus megaterium, Staphylococcus aureus, Strep. B-haemolyticus) and six Gram-negative bacteria (Escherichia coli, Salmonella typhi, Shigella dysenteriae, Shigella shiga, Klebsiella spp., Shigella boydii) were used for antibacterial activity study, four fungi (Aspergillus niger, Aspergillus fumigatus, Aspergillus flavus, Candida albicans) were used for antifungal activity study and a simple zoological organism (brine shrimp nauplii) was used for cytotoxicity study. All organisms were collected from the stock culture of the Institute of Nutrition and Food Sciences, University of Dhaka, Bangladesh. 


\subsection{Antibacterial, antifungal and cytotoxicity studies}

Antibacterial and antifungal activity studies were carried out by disc diffusion method [9, 10] and cytotoxicity was studied by brine shrimp lethality bioassay [11]. Standard antibiotic disc of Kanamycin (K-30 $\mu \mathrm{g} / \mathrm{disc}$ ) was used as the standard reference drug for antibacterial assay, Nystatin $(50 \mu \mathrm{g} /$ disc $)$ was used for antifungal activity study and gallic acid was used as a standard reference for cytotoxicity study [12].

\subsection{Chemical analysis by GC/MS}

The essential oils were examined by ISO-ext method in Agilent, 6890 series-GC system (made in USA). ISO-ext method is a long routine method to determine non-polar to polar compounds in a mixture. In this analysis, total running time was 73 min from $50^{\circ} \mathrm{C}(1$ min. hold) to maximum $300^{\circ} \mathrm{C}$ (10 min. hold) and ramp time was 4 min. Petroleum ether extract (1 gm) of Piper chaba root was dissolved in small amount of acetone and shaken in UV-water bath. Then acetone soluble fraction was collected and dried off by Nitrogen gas to afford an oily mass for the GC/MS analysis. $5 \mathrm{mg}$ of acetone soluble fraction was dissolved in $1 \mathrm{ml}$ of acetone. For this analysis, $1 \mu \mathrm{l}$ of samples was injected in split mode and selective mass detector with helium gas at $1.6 \mathrm{ml} / \mathrm{min}$ under 31.7 psi pressures and AV with $35 \mathrm{~cm} / \mathrm{sec}$ were used.

Table 1. Antibacterial activity of different extracts of the roots of Piper chaba.

\begin{tabular}{|c|c|c|c|c|c|c|c|c|c|}
\hline \multirow[b]{3}{*}{ Bacteria } & \multicolumn{9}{|c|}{ Diameter of zone of inhibition (mm) } \\
\hline & \multicolumn{2}{|c|}{$\begin{array}{c}P E \\
(\mu \mathrm{g} / \text { disc })\end{array}$} & \multicolumn{2}{|c|}{$\begin{array}{c}\mathrm{CE} \\
(\mu \mathrm{g} / \mathrm{disc})\end{array}$} & \multicolumn{2}{|c|}{$\begin{array}{c}\mathrm{EE} \\
(\mu \mathrm{g} / \mathrm{disc})\end{array}$} & \multicolumn{2}{|c|}{$\begin{array}{c}\mathrm{ME} \\
(\mu \mathrm{g} / \mathrm{disc})\end{array}$} & \multirow{2}{*}{$\begin{array}{c}\begin{array}{c}\text { Kanamycin } \\
(\mu \mathrm{g} / \mathrm{disc})\end{array} \\
30\end{array}$} \\
\hline & 50 & 200 & 50 & 200 & 50 & 200 & 50 & 200 & \\
\hline $\begin{array}{l}\text { Gram-positive } \\
\text { Bacillus subtilis }\end{array}$ & 9 & 16 & 9 & 17 & 14 & 30 & 15 & 28 & 24 \\
\hline Bacillus megaterium & 10 & 15 & 9 & 14 & 15 & 28 & 17 & 30 & 28 \\
\hline Staphylococcus aureus & 9 & 18 & 11 & 17 & 15 & 30 & 18 & 28 & 27 \\
\hline Strep. $\beta$-haemolyticus & 11 & 17 & - & 19 & 16 & 32 & 16 & 27 & 26 \\
\hline \multicolumn{10}{|l|}{ Gram-negative } \\
\hline Escherichia coli & 8 & 14 & 9 & 16 & 15 & 30 & 16 & 29 & 28 \\
\hline Salmonella typhi & 9 & 13 & 10 & 19 & 14 & 26 & 17 & 27 & 27 \\
\hline Shigella dysenteriae & 10 & 14 & - & 17 & 16 & 34 & 15 & 31 & 29 \\
\hline Shigella shiga & 10 & 15 & 9 & 18 & 13 & 29 & 16 & 25 & 28 \\
\hline Shigella boydii & 9 & 16 & 11 & 19 & 15 & 31 & 16 & 29 & 27 \\
\hline Klebsiella spp. & - & 12 & - & 15 & 16 & 28 & 17 & 27 & 26 \\
\hline
\end{tabular}

PE - Petroleum ether extract, CE - Chloroform extract, EE - Ethyl acetate extract, ME - Methanol extract, (-) - no inhibition. 


\section{Results}

The results of antibacterial test of various fractions of the extracts are presented in Table 1. The antibacterial activities of these extracts are compared to standard drug Kanamycin. It can be inferred from the table that the extracts, when compared to Kanamycin, show moderate activity against various types of bacteria. However, the pure compound(s) might show even higher antibacterial activities than Kanamycin. Table 2 shows antifungal activity of the crude extracts. In this case our results have also been compared to standard drug Nystatin. The extracts show antifungal property but the extent of inhibition is lower than that of Nystatin, even with higher doses.

Table 2. Antifungal activity of different extracts of the roots of Piper chaba.

\begin{tabular}{|c|c|c|c|c|c|}
\hline \multirow{3}{*}{ Test Fungus } & \multicolumn{5}{|c|}{ Diameter of the zone of inhibition (mm) } \\
\hline & $\mathrm{PE}$ & $\mathrm{CE}$ & $\mathrm{EE}$ & $\mathrm{ME}$ & Nystatin \\
\hline & $200 \mu \mathrm{g} /$ disc & $200 \mu \mathrm{g} / \mathrm{disc}$ & $200 \mu \mathrm{g} /$ disc & $200 \mu \mathrm{g} / \mathrm{disc}$ & $50 \mu \mathrm{g} / \mathrm{disc}$ \\
\hline $\begin{array}{l}\text { Aspergillus } \\
\text { fumigatus }\end{array}$ & 12 & 14 & 8 & 10 & 25 \\
\hline $\begin{array}{l}\text { Aspergillus } \\
\text { niger }\end{array}$ & 11 & 13 & 8 & - & 24 \\
\hline $\begin{array}{l}\text { Aspergillus } \\
\text { flavus }\end{array}$ & 10 & 10 & 9 & 8 & 20 \\
\hline $\begin{array}{l}\text { Candida } \\
\text { albicans }\end{array}$ & 12 & 13 & 10 & 10 & 15 \\
\hline
\end{tabular}

PE - Petroleum ether extract, CE - Chloroform extract,

EE - Ethyl acetate extract, ME - Methanol extract, (-) - no inhibition.

Table 3 shows brine shrimp lethality bioassay of various fractions of the extracts and a comparison has been made against a standard reference drug gallic acid. It has been found that petroleum ether, chloroform and ethyl acetate extracts were very potent cytotoxic $\left(\mathrm{LC}_{50}\right.$ values were less than $\left.4.5 \mu \mathrm{g} / \mathrm{ml}\right)$ in comparison to gallic acid $\left(\mathrm{LC}_{50}\right.$ value was 4.5 $\mu \mathrm{g} / \mathrm{ml})$.

Table 3. Cytotoxicity test of root extracts of Piper chaba.

\begin{tabular}{|c|c|c|c|c|c|}
\hline \multirow[t]{2}{*}{ Extracts } & \multirow{2}{*}{$\begin{array}{c}\mathrm{LC}_{50} \\
(\mu \mathrm{g} / \mathrm{ml})\end{array}$} & \multicolumn{2}{|c|}{$\begin{array}{l}\text { 95\% confidence limit } \\
(\mu \mathrm{g} / \mathrm{ml})\end{array}$} & \multirow[t]{2}{*}{ Regression equation } & \multirow[t]{2}{*}{$\lambda^{2}(\mathrm{df})$} \\
\hline & & upper & lower & & \\
\hline PE & 0.95 & 1.58 & 1.57 & $\mathrm{Y}=2.88+2.16 \mathrm{X}$ & $0.83(2)$ \\
\hline $\mathrm{CE}$ & 1.53 & 0.87 & 2.71 & $\mathrm{Y}=3.10+1.59 \mathrm{X}$ & $0.06(2)$ \\
\hline $\mathrm{EE}$ & 4.22 & 1.99 & 8.98 & $\mathrm{Y}=2.89+1.30 \mathrm{X}$ & $0.25(3)$ \\
\hline ME & 14.21 & 8.41 & 23.99 & $Y=2.97+1.75 X$ & $3.23(3)$ \\
\hline Gallic acid & 4.53 & 3.33 & 6.15 & $Y=3.93+1.62 X$ & $1.25(2)$ \\
\hline
\end{tabular}

PE - Petroleum ether extract, CE - Chloroform extract.

EE - Ethyl acetate extract, ME - Methanol extract, (-) - no inhibition.

$\lambda^{2}$ - Chi-square value, df - Degree of freedom. 
Gas chromatogram of the essential oils of petroleum ether extract of Piper chaba roots are shown in Fig. 1. From the GC/MS spectrum, a total of 44 peaks were identified. Some peaks were broad or mixture and some were very small which were not considered in analysis. Among the 44 peaks, the highest peak at retention time 52.14 min. possesses a basic signal at 152 in mass spectrum. It might be tri-beta-ketal skeleton compounds but could not be identified because of its $25 \%$ match with the existing library data. Out of 44

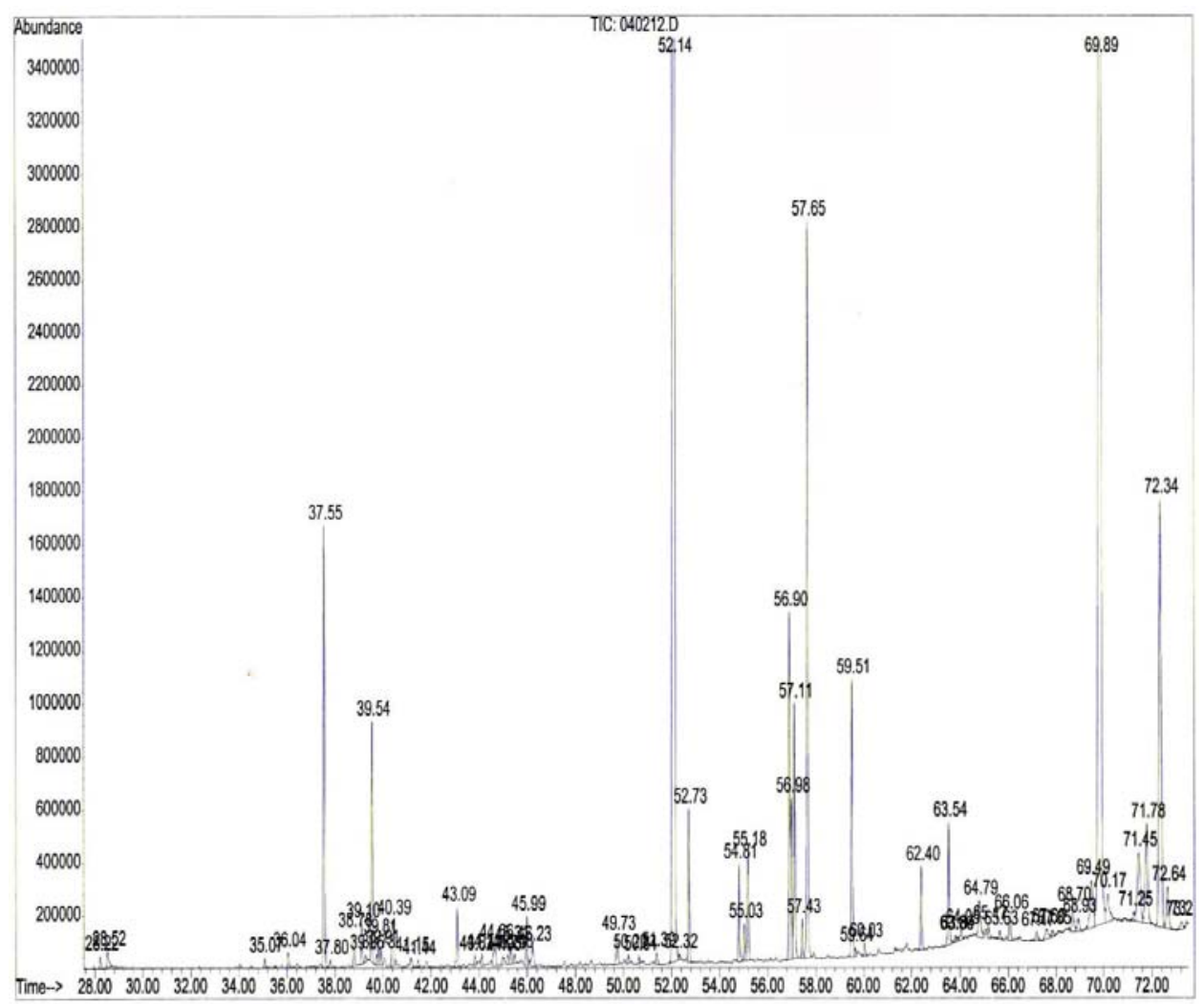

Fig. 1. Gas chromatogram of the essential oils of petroleum ether extract of Piper chaba roots.

peaks, 24 showed more than $80 \%$ match with the Wiley library data. The structures of only 17 compounds, which match more than 90\%, were confirmed. Most of the compounds were sesquiterpenes with molecular mass of 204, some were long chain fatty acids and some might be monoterpenes and alkaloids. At the early middle of the GC/MS spectra most of the peaks were known corresponding to the oily components but at the end of the spectra there were mainly unknown compounds. Chemical profile of the acetone soluble fraction of the petroleum ether extract of Piper chaba root by GC/MS is given in Table 4. 
Table 4. Chemical profile of the acetone soluble fraction of petroleum ether extract of Piper chaba roots by $\mathrm{GC} / \mathrm{MS}$.

\begin{tabular}{|c|c|c|c|}
\hline $\begin{array}{l}\text { Peak at retention } \\
\text { time (min.) }\end{array}$ & $\begin{array}{l}\text { Probable } \\
\text { mass }\end{array}$ & Possible compounds & \%Matching with Wiley library \\
\hline 35.07 & 149 & Heliotropine & 97 \\
\hline 36.04 & 204 & $\beta$-Elemene & 99 \\
\hline 37.55 & 204 & $\beta$-Caryophyllene & 99 \\
\hline 37.80 & 204 & Germacrene-D & 97 \\
\hline 38.78 & 204 & $\alpha$-Humulene & 98 \\
\hline 39.10 & 204 & $\alpha$-Amorphene & 98 \\
\hline 39.26 & 204 & (-)-Isoledene & 93 \\
\hline 39.54 & 204 & Germacrene-D & 99 \\
\hline 39.73 & 204 & Naphthalene & 97 \\
\hline 39.81 & 204 & $\alpha$-Muurolene & 98 \\
\hline 39.91 & 204 & $(+)$-Aromadendrene & 96 \\
\hline 40.39 & 204 & $\delta$-Cadinene & 98 \\
\hline 41.15 & 204 & (-)-Aromadendrene & 90 \\
\hline 41.44 & 204 & Elemol & 83 \\
\hline 43.09 & 161 & Caryophyllene oxide & 93 \\
\hline 43.82 & 220 & Cyclopropazulen-7-ol & 46 \\
\hline 44.11 & 220 & Spathulenol & 89 \\
\hline 44.66 & 204 & Germacrene-D & 86 \\
\hline 44.96 & 222 & T-Muurolol & 86 \\
\hline 45.20 & 204 & $\gamma$-Gurjunene & 83 \\
\hline 45.31 & 177 & 1H-Indole-3-carboxylic acid & 41 \\
\hline 45.48 & 204 & Thujopsene & 55 \\
\hline 45.99 & 162 & Cyclohexane compound & 35 \\
\hline 49.73 & 182 & Flopropione & 43 \\
\hline 50.20 & 241 & Ethyl heptadecanoate & 68 \\
\hline 51.39 & 192 & 1,8-Nonadiene & 38 \\
\hline 52.14 & 152 & Trimethyl-2-cyclohexene-1,4 dione & 25 \\
\hline 52.73 & 284 & Hexadecanoic acid ethyl ester & 98 \\
\hline 54.81 & 166 & 1,2-Benzenediol & 25 \\
\hline 55.18 & 194 & Benzoic acid & 47 \\
\hline 56.90 & 308 & Ethyl linoleate & 99 \\
\hline 65.98 & 251 & 6-Methoxy-2'-nitroaurone & 40 \\
\hline 57.43 & 312 & Ethyl stearate & 98 \\
\hline 57.65 & 235 & N-Cyclodecylidene & 30 \\
\hline 59.51 & 151 & Pyridine,4-butyl-1-oxide & 59 \\
\hline 62.40 & 207 & 4-Quinolinol & 38 \\
\hline 63.54 & 325 & N-Methyl-2-phenyl ethylamine & 59 \\
\hline
\end{tabular}


(Table 4 continued)

\begin{tabular}{cccc}
\hline $\begin{array}{c}\text { Peak at retention } \\
\text { time, }(\text { min. })\end{array}$ & $\begin{array}{c}\text { Probable } \\
\text { mass }\end{array}$ & Possible compounds & \% Matching with Wiley library \\
\hline 64.79 & 330 & Hexadecanoic acid & 81 \\
66.06 & 150 & Thymol & 38 \\
69.49 & 264 & 9,12 -Octadecadienal & 92 \\
69.89 & 285 & $\Delta$ 2-1,2,4-Triazoline-5-one & 43 \\
71.45 & 282 & 2,3-Biphenylene & 25 \\
71.78 & 152 & 2-Benzofuranone & 27 \\
72.34 & 135 & Benzothiazole & 64 \\
\hline
\end{tabular}

\section{Discussion}

The ethyl acetate extract of Piper chaba root shows a significant antibacterial activity, followed by methanol extract against both Gram-positive and Gram-negative bacteria. This result suggests that the root extracts of Piper chaba can be used for the treatment of fever, bronchitis and tuberculosis. The petroleum ether and chloroform extracts show moderate antibacterial activity but they exhibit very potent cytotoxic property with $\mathrm{LC}_{50}$ values of 0.95 and $1.53 \mu \mathrm{g} / \mathrm{ml}$, respectively, compared to standard gallic acid. This result supports the use of Piper chaba as anthelmintic in traditional medicine. All extracts show moderate antifungal activity. From GC/MS analysis, it is clear that the oily mass of petroleum extract of Piper chaba (root) possesses some sesquiterpenes plus some intermediate polar compounds which might be interesting for further isolation and investigation of biological activity.

\section{References}

1. R. N. Chopra, Indigenous Drugs of India (U.N. and Son's Private Ltd., India, 1958).

2. M. K. S. Krishnan, The useful plants of India (Publication and Information Directorate, CSIR, New Delhi, India, 1986).

3. M. A. Sumathykutty, J. M. Rao, K. P. Padmakumari, and C. S. Narayanan, Flav. Frag. J. 14, 279 (1999).

4. S. Tewtrakul, K. Hase, S. Kadota, T. Namba, K. Komatsu, and K. Tanaka, J. Essen. Oil Res. 12, 603 (2000).

5. N. Sawangjaroen, S. Subhadhirasakul, S. Phongpaichit, C. Siripanth, K. Jamjaroen, and K. Sawangjaroen, Parasitol. Res. 95, 17 (2005).

6. N. Sawangjaroen, S. Phongpaichit, S. Subhadhirasakul, M. Visutthi, N. Srisuwan, and N. Thammapalerd, Parasitol. Res. 98, 588 (2006).

7. M. T. U. Rahman, J. A. Shilpi, M. Ahmed, and C. F. Hossain, J. Ethnopharmacol. 99, 203 (2005).

8. T. Morikawa, H. Matsuda, I. Yamaguchi, Y. Pongpiriyadacha, and Y. Yoshikawa, Plant Med. 70, 152 (2004). doi:10.1055/s-2004-815493

9. A. W. Beur, W. M. M. Kirby, J. C. Sherris, and M. Turck, Am. J. Clin. Pathol. 45, 493 (1966).

10. A. L. Barry, Principle and Practice of Microbiology (Lea \& Fabager. Philadelphia, 1976).

11. B. N. Mayer, N. R. Ferrigni, J. E. Putnam, L. B. Jacobsen, D. E. Nichols, and J. L. Mclaughlin, Plant Med. 45, 31 (1982). doi:10.1055/s-2007-971236

12. M. K. Sarkar, D. Ergil, A. U. Tamer, and N. Sahin, Fitoterapia 69, 457 (1998). 